\title{
PENGEMBANGAN APRESIASI SENI RUPA SISWA SEKOLAH DASAR MELALUI PENDEKATAN KRITIK SENI PEDAGOGIK
}

\author{
Wan Ridwan Husen \\ Universitas Muhammadiyah Tasikmalaya \\ Jl. Taman sari Km 2,5 Kota Tasikmalaya \\ Email: wanridwanhusen@gmail.com
}

\begin{abstract}
The appreciation activities in elementary school are part of art education, with the frequency of doing appreciation, the students'aesthetic experience will increasingly be better. In addition, the students are expected to appreciate, realize the uniqueness of art work so that later can be applied with respect each others, and train their sensitivity to themselves and others. Pedagogic art critic is an art criticism activity conducted in schools or art education institutions, by this art criticism is expected to be the ilustration of method, goal or strategy in teaching fine arts to increase the students' appreciation in developing their own potential.
\end{abstract}

Keywords:

Pedagogic art critic, appreciation, fine arts, elementary school fine arts

\begin{abstract}
Abstrak
Kegiatan apresiasi di sekolah dasar merupakan bagian dari pendidikan seni rupa, dengan seringnya melakukan apresiasi maka pengalaman estetis siswa pun akan semakin baik, dengan berapresiasi siswa diharapkan dapat menghargai, menyadari keunikan sebuah karya seni sehingga nantinya bisa diaplikasikan dengan menghargai sesama, serta melatih sensitivitas mereka terhadap dirinya sendiri dan orang lain. Kritik seni pedagogic merupakan kegiatan kritik seni yang dilakukan di sekolah atau instansi pendidikan seni, dengan kritik seni pedagogic ini diharapkan menjadi gambaran akan metode, tujuan atau strategi dalam mengajar seni rupa untuk meningkatkan apresiasi siswa dalam mengembangkan potensi yang ada pada dirinya. Penelitian ini merupakan usaha dalam mencari essensi dari makna apresiasi seni rupa untuk siswa sekolah dasar melalui kritik seni pedagogic, penelitian ini menggunakan metode kualitatif deskriptif yang diharapkan dapat menguraikan permasalahan untuk memecahkan masalah dengan cara study literasi, untuk kemudian dapat diterapkan di sekolah dasar.
\end{abstract}

Kata kunci:

Kritik seni pedagogic; apresiasi; seni rupa tingkat sekolah dasar.

\section{A. PENDAHULUAN}

Banyak cara belajar dalam kegiatan seni rupa di sekolah dasar, selain dari berkreasi, tanya jawab, kegiatan berapresiasi telah menjadi hal yang banyak dilakukan di sekolah, memperlihatkan karya-karya yang ada dalam sebuah slide atau berkunjung ke museum dan pameran contohnya, namun dalam dunia seni rupa ada sebuah istilah yaitu "kritikus" yang mana menjadi bagian tak terpisahkan dalam dunia kesenian. Untuk kemudian bagaimana jika dikenalkan prosesnya atau konsep dasar bagaimana memahami seni atau barangkali sebenarnya sudah dilakukan hanya saja istilah nya tidak digunakan.

Tulisan ini merupakan gagasan lanjutan penelitian penulis membahas kritik seni, menjadi sebuah ide bagaimana sebuah kritik bisa di aplikasikan di sekolah dasar dalam peningkatan apresiasi sebagai tindakan terhadap proses kreasi setelah mereka berkreasi. Penelitian ini merupakan usaha dalam mencari essensi dari makna apresiasi 
seni rupa untuk siswa sekolah dasar melalui kritik seni pedagogic, penelitian ini menggunakan metode kualitatif deskriptif yang diharapkan dapat menguraikan permasalahan untuk memecahkan masalah dengan cara study literasi, untuk kemudian dapat diterapkan di sekolah dasar.

Sekolah adalah rumah kedua bagi siswa dimana mereka menghabiskan banyak waktu disana untuk belajar dan bermain, menjadikan sekolah menjadi rumah yang nyaman adalah kewajiban guru dan sekolah. Kritik seni pedagogic merupakan proses menghargai orang lain dan diri sendiri melalui materi seni rupa.

\section{B. HASIL DAN PEMBAHASAN \\ 1. Pendidikan Seni Rupa di Sekolah Dasar}

Pengembangan apresiasi seni untuk SD hendaknya mengutamakan kegiatan praktek, tidak hanya ceramah atau mengisi soal saja, kegiatan praktek dilanjutkan dengan mengevaluasi dengan kegiatan kritik seni, diharapkan selain berkreasi siswa melakukan apresiasi. Kritik seni pedagogic diarahkan supaya siswa dibimbing untuk membicarakan karyanya atau mengapresiasi karya temannya, guru merangsang agar siswa menceritakan bagaimana kehidupan atau minat siswa terhadap apa yang mereka buat kedalam sebuah karya, selain menelusuri latar belakang karya, siswa diharapkan berani mengungkapkan gagasan berkarya baik secara lisan maupun secara tulisan. Sebuah kutipan berikut menyatakan tujuan pendidikan seni yang bisa kita jadikan pijakan bagaimana mengajar seni, khususnya pada sekolah tingkat dasar "Tujuan pendidikan seni adalah mengembangkan pengalaman estetik siswa agar memiliki kepekaan dan kepedulian terhadap sesuatu yang indah, mudah dan cermat menerima rangsangan dari luar, mudah tersentuh nuraninya sehingga menjadi manusia yang sensitive.”(jazuli,2008:18).
Untuk sekolah tingkat dasar keberanian dalam berkarya dan menunjukan apa yang telah ia buat sudah bisa dikatakan baik, karena tahapan dalam berapresiasi membutuhkan waktu yang panjang, semakin sering berapresiasi maka kepekaan akan estetika akan terlatih dengan sendirinya. "Melalui pengalaman estetik, siswa diharapkan dapat menginternalisasi (meresapi, mengakarkan) nilai-nilai estetik yang berfungsi untuk melatih kepekaan rasa, kecerdasan intelektual dan mengembangkan imajinasinya. "( jazuli, 2008:16).

Pendidikan seni rupa disekolah dasar masuk kedalam rumpun seni budaya dimana siswa akan dikenalkan belajar macam-macam seni baik rupa, tari, music dan drama. Khusus membahas materi seni rupa telah banyak materi yang diberikan sesuai dengan buku ajar seni budaya, namun tidak menutup kemungkinan guru berkreasi dari pengalaman atau dari pelatihan untuk diajarkan kepada siswanya. Menggambar merupakan materi yang sudah lumrah banyak dipelajari di semua sekolah, sumber belajarnya baik dari buku ajar, internet atau guru yang senang berkreasi dengan mencipta, mewarnai atau melanjutkan gambar.

Dengan kata lain belajar menggambar sudah banyak diterapkan untuk berbagai keperluan pendidikan seni rupa. "Kegiatan menggambar anak penting untuk mengembangkan kemampuan berfikir dengan rupa (membayangkan) yang bersama dengan kemempuan berfikir dengan kata akan memperlancar proses kreasi kelak, dibidang apapun kita berkiprah" (Tabrani,2000:13) seperti dinyatakan dalam kutipan Primadi bahwa menggambar tidak spesifik untuk menjadikan siswa sebagai seniman, namun apapun karier siswa kelak proses kreasi akan sangan bermanfaat bagi semua siswa.

Apabila mendalami pendidikan di sekolah formal, pendidikan seni rupa ternyata tidak saja terjadi di kelas, banyak siswa yang mengikuti perlombaan seni rupa, baik itu 
permintaan orang tua atau kepercayaan diri dari sekolah kepada muridnya untuk mengharumkan nama sekolah, untuk tingkat sekolah dasar, lomba yang banyak diadakan diantaranya adalah "lomba gambar". Pelombaan menggambar merupakan salah satu kegiatan yang bisa memicu minat seseorang supaya bertindak lebih, lebih banyak berlatih, lebih banyak melihat karya yang baik, lebih banyak waktu yang diluangkan untuk meningkatkan kemampuan siswa. Namun akan jadi salah kaprah apabila tujuan akhir dari berlatih adalah juara, karena sejatinya yang dibutuhkan anak usia sekolah dasar merupakan prosesnya, seperti mencoba berbagai teknik dan mencoba berbagai media sehingga melatih kepekaan dirinya terhadap sebuah karya, seperti diungkapkan oleh Primadi dalam sebuah buku nya yang membahas apresiasi sebagai berikut "Bagi anak yang penting prosesnya, kegiatan menggambarnya, bukan hasilnya.

Oleh sebab itu kurang baik bila terlalu banyak ikut lomba gambar anak. Lomba gambar sebaiknya sekedar sebagai motivasi, bukan tujuan" (Tabrani,2000:13). Pendidikan seni di sekolah formal selain melatih kemampuan motoric juga merupakan pendidikan sikap, pendidikan karakter dan juga melatih sensitivitas terhadap sesama. Dalam pelaksanaanya dilapanga sering terjadi hilaf, ketika anak hanya dituntut bisa atau mahir dalam seni, namun essensi dari pendidikan seni itu terlupakan.

Jika membahas pelajaran menggambar di sekolah dasar kutipan primadi layak untuk kita simak bagaimana kedudukan seni rupa pada anak sehingga materi ini harus ada, namun kembali lagi kepada kemampuan guru sebagai fasilitator siswa menuju hasil yang ingin diraih.

"Tidak ada anak yang tidak suka menggambar. Bila ada yang "tidak suka" menggambar, pasti ada sebabnya. Oleh sebab itu kegiatan seni rupa selalu ada di semua sanggar kegiatan anak. Kegiatan seni rupa anak informal terbuka bagi semua anak, bukan hanya bagi yang berbakat. Disaat menggambar, eksperimen,ekspresi, kreasi melebur dalam permainan "menggambar" yang sekaligus merupakan proses belajar. Kesemuanya melebur dalam penghayatan dimana terlibat keseluruhan diri anak: terpadu trio fisik-kreatif-rasio, indra-indra, bentuk dan sumber imaji lengkap dengan film dan nuansanya, seakan apa yang digambarnya itu benarbenar terjadi dan bukan sekedar tugas menggambar. Anak masih berfikir dengan rupa (gambar dan gerak) daripada dengan kata. Pendidikan seni rupa perlu mengembangkan kemempuan berfikir dengan rupa yang bersama dengan kemampuan berfikir dengan kata (yang berkembang belakangan), penting artinya untuk memungkinkan proses kreasi kelak, dibidang apapun kita berkiprah. Apapun yang dihasilkan manusia, ilmu dan teknologi khususnya sesampainya pada manusia umumnya melalui wujud rupa. Jadi pendidikan seni rupa merupakan sesuatu yang penting." (Tabrani,2000:73)

Banyak hal yang bisa dibicarakan dalam diskusi karya siswa sekolah dasar, diantaranya membahas apa judul atau tema yang dibuat, kemudian objek apa yang buat dari pemahaman mereka menangkap sebuah judul, apa yang tampak, apa yang menarik sampai pada kesan apa yang didapat. Bagaimana pengolahan warna, arahkan mereka membicarakan bagaimana teknik dalam pewarnaan atau mana warna yang disukai, kemudian pembicaran dilanjutkan mengenai komposisi atau penempatan objek, bagaimana kesesuaian ukuran gambar dengan bidang gambar dalam proses presentasi ini bimbingan guru sangatlah penting sebagai fasilitator dan pemberi penjelasan kepada siswa yang mendengarkan, bagaimana sebuah keseimbangan sebuah karya bisa menjadi inspirasi tersendiri atau bagaimana mereka mengeksekusi penempatan sebuah objek pada 
sebuah karya. Kemudian bebaskan mereka mengksplorasi media yang dipakai, kebebasan dalam memilih media akan menghasilkan karya yang beragam, pengunaan teknik dalam berbagai media, sifat khas media serta melihat orang lain menggunakannya.

Pendidikan seni rupa di tingkat sekolah dasar menjadi sebuah keharusan ketika proses kreasi dan apresiasi ini berjalan berdampingan, tidak timpang hanya kreasi atau hanya banyak di tahap apresiasi saja, hal ini akan sangat mempengaruhi kualitas pribadi siswa tersebut. Keberhasilan pendidikan seni rupa ini akan kembali pada kemampuan guru memahami karakteristik seni rupa anak untuk diterapkan sesuai pada periodisasi seni rupa anak sesuai dengan porsinya.

\section{Apresiasi}

Di sadari atau tidak, kegiatan apresiasi telah banyak di gunakan sebagai salah satu kegiatan pembelajaran seni rupa di sekolah, dengan berbagai metode yang digunakan, hasil dari kegiatan apresiasi ini tidak saja untuk sebagai sarana memahami atau menghargai karya seni, tetapi penting bagi siswa untuk mengimplementasikan dalam menghargai berbagai perbedaan yang dijumpai dalam keseharian mereka,.

Dengan belajar berapresiasi mereka juga didorong untuk menumbuhkan sensitifitas baik terhadap sesama atau terbangunnya kepedulian terhadap karya seni dan warisan budaya bangsa. Secara umum istilah apresiasi seni atau mengapresiasi karya seni berarti memahami sepenuhnya seluk-beluk karya seni serta menjadi sensitif (peka) terhadap segisegi estetikanya. Dalam sebuah kutipan berikut dijelaskan bagaimana apresiasi membentuk seseorang menjadi sensitive, serta melatih bagaimana mengamati dan berani menggapi sebuah karya seni,

"Apresiasi mengerti dan menyadari sepenuhnya seluk beluk hasil seni serta menjadi sensitive terhadap segi-segi di dalamnya, sehingga mampu menikmati dan menilai karya dengan semestinya. Kemampuan mengamati dan menanggapi karya seni atau bentuk visual atau tekstual yang ada dalam karya seni, disana bukan sekedar kemampuan mencatat ciri-ciri (atau data) yang ada pada objek, namun lebih dari itu, kesanggupan menemukan kandungan objek itu menjadi penting. Beberapa hal yang penting dalam mengamati/mengapresiasi karya seni adalah seringnya mengamati (perception constancy), latar belakang informasi, kondisi psikologi saat mengamati karya" (susanto, 2003:27)

Adapun pendapat lain mengenai apresiasi,

"Berapresiasi (to appreciate) berarti menghargai. Kata menghargai melibatkan dua pihak, yaitu subjek sebagai pihak yang memberi penghargaan dan objek yang bernilai sebagai pihak yang dihargai. Subjek akan memberikan penghargaan dengan tepat apabila ia mampu mengamati dan menilai apa yang bermakna dalam objek. Sesungguhnya, semua pengertian yang menambah pengetahuan dan pengalaman kita adalah sesuatu yang kita hargai. Oleh karenanya berparesiasi dapat memberi kepuasan intelektual, mental dan spiritual seseorang. Dari sinilah pentingnya kegiatan berapresiasi dalam pendidikan seni karena siswa memperoleh pengalaman menyerap, menyaring, menyikap, mentafsirkan dan menanggapi gejala estetik baik pada karya seni maupun alam. Dengan pengalaman seperti itu dapat dikembangkan pula kepekaan terhadap gejala-gejala lain, seperti gejala yang berhubungan dengan segala fenomena kehidupan, etik-moral, dan ketuhanan. Dengan kata lain bahwa dalam kegiatan berparesiasi potensi afeksi siswa menjadi focus dan sasaran perhatian agar lebih berdaya dan berkembang. " ( jazuli, 2008:80) 
Apresiasi seni merupakan suatu proses penghayatan karya seni, selain melihat karya secara langsung proses apresiasi disini merupakan pencarian informasi sedalamdalamnya mengenai latar belakang dan form(bentuk) pada sebuah karya, Sehingga terbentuklah pengalaman menerima atau menolak, setuju atau tidak, senang atau kurang menyenangi sesuatu, sehingga pada akhirnya mereka memiliki kepekaan baik sebagai apresiator maupun memiliki gaya individual sebagai creator/seniman.

Dalam pelaksanaannya, tentu saja tahapan dalam proses berapresiasi sangat dibutuhkan, sehingga diharapkan dengan banyaknya melihat unsur-unsur artistik, maka terciptalah pengalaman estetik yang nantinya akan mereka butuhkan baik ketika mereka berperan baik sebagai apresiator maupun sebagai creator seni. Selanjutnya mereka akan memilih hal-hal apa yang secara individual menarik bagi dirinya, dalam kegiatan berapresiasi proses menikmati, menghayati dan merasakan suatu objek seni juga mencermati karya seni dengan mengerti dan peka terhadap segi-segi estetiknya, diharapkan mampu memaknai karya seni tersebut dengan semestinya.

Pada pelaksanaanya dilapangan kegiatan apresiasi ini tidaklah sepenuhnya menjadi tanggung jawab penuh guru terhadap siswa nya, seperti dijelaskan Juju dalam kutipan berikut bahwa lingkungan dan keluarga hendaknya mendukung kearah pendidikan yang lengkap, dimana sekolah formal terus berbenah memperbaiki apa yang kurang kemudian didukung dengan adanya penguat berupa pendidikan nonformal atau informal, maka proses apresiasi ini akan lebih efektif.

"Untuk meningkatkan apresiasi seni dan budaya dalam pendidikan di Indonesia diperlukan jalinan kerjasama yang bahu membahu dari berbagai pihak. Benang kusutnya pendidikan seni di sekolah formal kita mesti di benahi pada kurikulum, bahan ajar yang digali dari bumi indonseia, profesionalisme guru, dan pemahaman para pentu kebijakan. Dalam mendukung pendidikan seni yang lebih baik, maka diperlukan pula pola pendidikan informal (keluarga, masyarakat), dan pendidikan non formal (sanggar,padepokan, perkumpulan ) "(Marsunah,2003:296)

Apresiasi berarti menerima, menghargai melalui proses yang melibatakan rasa dan fikir. Di mana proses melatih kepekaan siswa, kegiatan apresiasi dilakukan dengan berbagai metode yang merupakan gabungan antara aspek pengamatan dan penghayatan, melalui teknik bertanya dan menunjukkan unsur-unsur menarik dari suatu karya. Kegiatan apresiasi tidak hanya dilakukan di kelas saja dengan cara guru memperlihatkan karya-karya terkenal kepada siswanya pada jam pelajaran, kunjungan pameran atau museum seni sudah menjadi hal biasa dilakukan, di selengarakan nya pameran di sekolah merupakan kegiatan apresiasi yang eefektif guna meningkatkan apresiasi siswa.

Peningkatan apresiasi melalui pendekatan kritik seni rupa pedagogic dapat dilakukan dari tingkat dasar yang sederhana, yaitu dari hasil karya siswa yang dipresentasikan, dibantu dengan arahan dari guru siswa dibimbing untuk membahas atau berdiskusi mengenai kekaryaan mereka, ketika mereka berani saling berpendapat, inilah yang dimaksud dengan kritik seni pedagogic, setelah terjadi Tanya jawab catatan disini penting bagi guru dan siswa nya, selain sebagai evaluasi karya bertukar pendapat dari masing-masing siswa menjadi point tambah bagi pembelajaran apresiasi. Maka ketika guru membuat kesimpulan bagaimana karya mereka dibahas, maka diharapkan adanya perkembangan dari karya yang sudah jadi dikembangkan kembali pada karya berikutnya. 
Dalam melaksanakan diskusi ini baiknya guru memulai dengan memahami keberanian siswa dalam berbicara, memahami bagaimana teknik yang telah siswa kuasai untuk kemudian dibahas dalam diskusi. Sudah menjadi baik apabila pembicaraan sudah sampai pada tahap penjelasan sejarah dan pengetahuan mengenai kesenian oleh guru terhadap siswanya, Kutipan berikut menyatakan bagaimana berapresiasi terhadap sebuah karya seni, sebagian bisa kita pelajari bagaimana cara mencari masalah untuk dibicarakan atau dipertanyakan dalam belajar apresiasi

"Untuk pembelajaan apresiasi seni ini digunakan cara pendekatan aplikatif dan kesejarahan. Pendekatan aplikatif berkaitan dengan kegiatan berkarya kreatif. Pendekatan kesejarahan ialah apresiasi seni yang ditempuh melalui pengenalan sejarah seni: penciptaan demi penciptaan, peristiwa demi peristiwa yang masing-masing memiliki problemnya sendiri, dibicarakan dan dibahas. Dengan demikian, problemnya sendiri, dibicarakan dan dibahas. Dengan demikian, diharapkan orang akan memahami apa-apa yang ada dibalik tiap penciptaan itu dan selanjutnya memungkinkan baginya untuk menikmatinya. Tujuan akhir dari pembelajaran tersebut diharapkan siswa dapat menghargai kompleksitas seni dan budayanya. "(Marsunah,2003:286)

Banyak hal yang harus dilakukan seorang guru (dalam hal ini yang berperan sebagai pendidik) untuk melatih kepekaan apresiasi siswa nya. Bukan hanya nilai di raport saja yang menjadi hasil, namun pendidik mempunyai tanggung jawab mengenai perubahan sikap, mengenai kepekaan sensitivitas siswa nya terhadap sesama dan terhadap lingkungan sekitar.

\section{KRITIK SENI PEDAGOGIK}

Jika dilihat dari sejarahnya, pengertian kritik seni sudah ada sejak jaman Romawi diambil dari kata Kritik : pada zaman Yunani, Krinein yag berarti memisahkan, mengamati, membandingkan, dan menimbang. Perkembangan kritik seni mengalami beberapa perubahan kritik seni dulu pada masa Renessance: lebih bersifat Menghakimi dan kritik seni sekarang justru lebih Mengevaluasi (meninjau). Makna karya seni adalah filosofis dan metaforik (kiasan) maka akan sulit dalam penyampaian pesan dan ide atau gagasan yang ingin disampaikan creator pada para apresiator, maka tugas seorang kritikus-lah yang mengambil peran penting untuk tujuan pengakuan apresiator terhadap kaya seni itu.

Perkembangan kritik seni rupa, dipilah oleh banyak ahli seni rupa Barat menjadi empat jenis, yakni kritik Jurnalistik, kritik Pedagogik, kritik Ilmiah dan kritik Populer. "Setiap jenis kritik ditentukan berdasarkan bentuk, karakter, fungsi, peran dan lingkup pemanfaatannya"(Mamanoor, 2002:43). Adapun pemilahan keempat jenis kritik ini pertama kali diungkapkan oleh E.B.Feldman yang mempunyai bebererapa kelebihan, sehingga dipakai hingga kini. "Teori Feldman memiliki kenggulan dalam hal struktur nya yang sederhana, tetapi dapat menampung semua kecenderungan penilaian seni yang ada dan tidak terikan zaman maupun aliran seni" (Bangun, 2000: 7).

Kritik seni pedagogic merupakan salah satu jenis kritik dalam seni rupa. Dilihat dari segi keilmuan, Sem C. Bangun (2000:1) menyatakan bahwa kritik seni merupakan kegiatan perseorangan. Dipandang dari segi keilmuan, kritik seni rupa adalah pengetahuan toeritis dan teknis penilaian mengenai presentasi kesenirupaan. Dari segi proses, kritik seni rupa adalah kegiatan perorangan, baik lisan maupun tulisan, yang dipublikasikan kepada khalayak ramai. dari segi produk kritik seni rupa adalah sekumpulan hasil opini para pengamat tentang 
presentasi kesenirupaan yang mengandung nilai apresiatif, edukatif, dan dokumentatif.

Kritik seni pedagogic merupakan kegian kritik seni yang biasa terjadi di sekolah atau instansi seni, kritik pedagogic merupakan tipe kritik yang dilakukan oleh seorang guru (pendidik) terhadap karya siswanya dalam mengembangkan proses pembelajaran kreasi dan apresiasi.

Dalam proses pembelajaran, seorang pendidik memiliki peranan sebagai seorang kritikus karya-karya siswa sebagai motivasi, responsi, evaluasi, reinforcement. Peranan pendidik tersebut berfungsi untuk membina kemandirian kreasi dan ekspresi Siswa. Dari sudut kependidikan, kritik merupakan hal yang integratif dengan sistem pembelajaran. Kritik dalam proses belajar-mengajar akan selalu muncul tak terpisahkan dengan dengan metode, strategi dan evaluasi.

Kritik lisan yang disampaikan Pendidik dalam kelas terhadap karya Siswa sebagai bukti bahwa Pendidik berusaha untuk membangun artistic personality Siswa. Pada dasarnya Seorang Kritikus adalah seorang yang mengulas (menafsir) (mengurai) dan kritikus merupakan seorang pencela dan harus merupakan seorang yang kritis, karena dalam kenyataanya Seniman tidaklah berbicara dalam karyanya tetapi itu merupakan tugas seorang kritikus. Dalam bukunya Diksi Rupa (Kumpulan Istilah Seni Rupa), Mikke Susanto menulis bahwa Kritikus Seni Rupa adalah seorang ahli kritik seni, yang mempertimbangkan karya dan wacana seni rupa, kemudian merumuskannya secara profesional. Seorang kritikus adalah orang yang paham akan proses kreatif, dalam buku Jacob Sumarjo dinyatakan bahwa tugas, kewajiban, dan peran kritikus adalah perintis pendidikan dan pembentuk tradisi budaya suatu masyarakat. Jadi peran utama seorang kritikus adalah sebagai pendidik masyarakat dan ikut mencoba memberikan rumusan bentuk budaya masyarakatnya, karena
Nortrop Freye mengatakan bahwa seni itu bisu dan kritik yang berbicara.

Sem.C.Bangun menyatakan dalam bukunya yang berjudul Kritik Seni bahwa "Pada dasarnya kritik seni Pedagogik diterapkan dalam kegiatan proses belajar mengajar dilembaga pendidikan kesenian" (Bangun , 2000:9). Karena selain membekali wawasan siswa akan cara-cara melakukan apresiasi terhadap karya seni. kritik Pedagogik ini diterapkan dalam upaya untuk menerapkan pengetahuan-pengetahuan dan pembinaan siswa pada pendekatan kritik seni. "Kritik Pedagogik dimaksudkan untuk memajukan kematangan artistik dan estetik para siswa. Jenis kritik ini tidak dilakukan untuk membuat kritik yang bersifat otoritatif, agar para siswa dapat membuat kritik atas diri mereka sendiri"(Dharsono, 2007:55).

Contoh kegiatan kritik seni pedagogic yang bisa dilakukan guru sekolah dasar terhadap siswanya diantaranya melalui kegiatan berbincang-bincang mengenai karya yang telah dibuat siswa, disini guru berperan sebagai fasilitator, selain sebagai membuat diskusi menjadi kondusif juga memberikan pemahaman-pemahaman baru terutama bagaimana bersikap atau berapresiasi terhadap sebuah karya.

Guru bisa saja membahas bagaimana Gaya, Teknik, Tema, Komposisi dari karya siswa maupun karya terkenal seniman besar, karena kritik seni pada dasarnya merupakan kegiatan menanggapi karya seni. Perbedaannya hanyalah kepada fokus dari kritik seni yang lebih bertujuan untuk menunjukkan kelebihan dan kekurangan suatu karya seni. Keterangan mengenai kelebihan dan kekurangan ini dipergunakan dalam beragam aspek, terutama sebagai bahan untuk menunjukkan kualitas dari sebuah karya.

Dalam dunia pendidikan, kegiatan kritik dapat digunakan sebagai bahan evaluasi dalam proses pembelajaran seni. Kekurangan pada sebuah karya dapat dijadikan bahan analisis untuk meningkatkan kualitas proses 
pembelajaran maupun hasil belajar kegiatan apresiasi yang tentang seni.

"kritik pedagogic dimaksudkan untuk memajukan kematangan artistic dan estetik para siswa. Jenis kritik ini tidak dilakukan untuk membuat kritik yang bersifat otokratif, agar siswa dapat membuat kritik atas diri mereka sendiri. Dalam menangani para siswa. Guru yang dalam hal ini berfungsi sebagai kritikus haruslah dapat membedakan dengan kritik professional . pendapat ataupun standar professional dapat diajukan untuk memberikan stimulasi dan membicarakannya dalam diskusi." (Darsono 2007: 55)

Untuk pembahasan karya, guru bisa saja menggunakan teknik pembahasan dari kritik seni, seperti kritik formalistik, kritik ekspresivistik dan instrumentalistik. Di mana melalui pendekatan formalistik, kajian kritik ditujukan terhadap karya seni sebagai konfigurasi aspek-aspek formalnya atau berkaitan dengan unsur-unsur pembentukannya, atau melalui pendekatan ekspresivistik dalam kritik seni, disini guru (sebagai kritikus) cenderung menilai dan menanggapi kualitas gagasan dan perasaan yang ingin dikomunikasikan oleh seniman melalui sebuah karya seni, dan yang terakhir Melalui pendekatan instrumentalistik, dimana sebuah karya seni cenderung dikritisi berdasarkan kemampuananya dalam upaya mencapai tujuan, moral, religius, politik atau psikologi. Pendekatan kritik ini tidak terlalu mempersoalkan kualitas formal dari sebuah karya seni tetapi lebih melihat aspek konteksnya baik saat ini maupun masa lalu.

\section{SIMPULAN}

Untuk sekolah dasar tentu bukan hal mudah dalam membiasakan siswa melakukan pembicaraan mengenai karya pada siswa terhadap siswa yang lain, namun gagasan dari tulisan ini adalah "apa yang dilakukan setelah berkreasi?" Atau "bagaimana menyikapi karya setelah mereka selesai?" dalam menggambar misalkan. Kritik seni disini berarti mengajak kepada mendiskusikan atau membahas satu-persatu dari karya yang ada, sehingga selain siswa berani berekspresi melalui gambar, mereka juga mulai membiasakan diri dalam berargumen atau berbicara dihadapan teman-teman sekelasnya perihal gagasan, ide, cara, teknik, harapan bahkan cita-cita yang sudah tergambar pada karyanya.

Pada akhirnya, peran guru sebagai kritikus di kelas adalah menjadi penentu bagaimana proses apresiasi siswa bisa dilakukan, sikap saling menghargai sesama atau menghargai diri sendiri merupakan hal yang baik apabila dilakukan semenjak usia sekolah dasar.

\section{DAFTAR PUSTAKA}

Bangun, S. Kritik Seni Rupa, Bandung: Penerbit ITB. (2000).

Dharsono, Kartika S. Kritik Seni. Bandung : Rekayasa Sains. (2007).

Jazuli, Prof. Dr. M,Hum. (2008). Paradigma Kontekstual Pendidikan Seni. Semarang: Unesa University Press.

Laura Lipton dan Deborah Hubble Sekolah kreatif. Bandung: Penerbit Nuansa Cendikia. (2013)

Masunah, Juju \& Narawati. Seni dan Pendidikan Seni (Sebuah Bunga Rampai). Bandung : Pusat Penelitian dan Pengembangan Pendidikan Seni Tradisional (P4ST) Universitas Pendidikan Indonesia. (2003).

Pamadhi, Hajar. Drs. MA Pendidikan Seni (Hakikat,Kurikulum Pendidikan Seni, Habitus seni dan pengajaran seni untuk anak), UNY Press, Yogyakarta. (2012)

Sumardjo, Jacob. Filsafat seni. Bandung: ITB. 2010.

Susanto,Mikke. Diksi rupa: kumpulan istilah \&gerakan seni rupa, Dictiartlab \&jagad arthouse, Yogyakarta. (2011) 
Susanto,Mikke. Membongkar Seni Rupa, Penerbit Buku Baik dan Penerbit Jendela, Yogyakarta. (2003)

Tabrani, Primadi. Proses kreasi, apresiasi, belajar. Bandung: ITB Press, (2000). 